\title{
educação

\section{Entre a fralda e a lousa: A questão das identidades docentes em berçários}

\author{
Rosmari Pereira de Oliveira ${ }^{i}$ \& Luciana Maria \\ VIVIANI $^{\text {II }}$
}

\author{
Universidade de São Paulo, Brasil
}

\begin{abstract}
Neste artigo apresentamos uma pesquisa sobre identidades docentes em berçários desenvolvida em um Centro de Educação Infantil na cidade de São Paulo (Brasil). Mediante enfoque qualitativo e multidisciplinar, o estudo buscou tecer relações entre identidade, cultura, gênero e poder, aproximando a área dos estudos culturais ao campo da educação infantil. Inspirado em abordagens biográficas, o estudo empírico foi realizado através de entrevistas com sete professoras e um professor de educação infantil, que atuavam com crianças de 0 a 2 anos de idade. As análises indicaram que, embora a prática nos berçários envolvesse múltiplos saberes e culturas, produzia-se nos discursos dos professores um binarismo sobre a necessidade de cuidar e educar em que cuidar associava-se às práticas do passado e educar aproximava-se ao seu novo papel profissional, representando estratégias identitárias para valorizar a docência com bebês.
\end{abstract}

Palavras-chave: Identidades docentes; Educação infantil; Culturas institucionais

\section{IN T R O D U Ç Ã O}

O presente artigo apresenta os resultados obtidos em uma pesquisa desenvolvida em um Centro de Educação Infantil (CEI) na cidade de São Paulo sobre a questão das identidades docentes em berçários daquela instituição. Buscando aproximar a abordagem dos estudos culturais ao campo da educação infantil, a investigação teve como pressupostos teóricos algumas concepções de Stuart Hall, Nestor Canclini e Michel Foucault, entre outros, para tecer relações entre identidade, cultura, gênero e poder, em um enfoque interdisciplinar.

Analisamos o processo de construção das identidades profissionais de docentes que atuavam com crianças de 0 a 2 anos de idade, considerando as demandas específicas desse campo de trabalho e as rupturas, descontinuidades e permanências ocorridas nessa carreira no âmbito dos CEIs nas últimas décadas, na cidade de São Paulo. O estudo empírico teve enfoque qualitativo, inspirado em abordagens biográficas, e tomou como base entrevistas realizadas com sete professoras e um professor, na faixa etária de 26 a 61 anos, que trabalhavam nesse CEI, aqui denominado de CEI Freireano.

Considerando o histórico recente da instituição, com ênfase à passagem das creches, 
hoje CEIs, do âmbito de órgãos assistenciais para a Secretaria Municipal de Educação, em 2001, e partindo da análise das narrativas das docentes e do docente, procuramos identificar aspectos relevantes para a compreensão do processo de constituição de suas identidades profissionais diante das demandas do trabalho específico com bebês no contexto daquela rede pública de ensino. Tomamos como base a trajetória de vida pessoal e profissional de cada um dos sujeitos; as questões de gênero que permeiam a prática docente no campo específico da educação infantil; os fazeres e saberes constituídos em suas práticas com os bebês, bem como as suas próprias percepções e representações sobre a docência.

Tendo uma das autoras deste estudo atuado na gestão de creches públicas na cidade de São Paulo de 1991 a 2011, e também como formadora de profissionais da educação infantil, houve a oportunidade de acompanhar de perto as mudanças estruturais ocorridas nesse período na instituição, especialmente as transformações no quadro de pessoal que culminaram com o surgimento dessa nova categoria de profissionais. Com base nessas vivências, ficou evidente que "a fralda" representava, naquele contexto, um símbolo quase emblemático no que se refere aos cuidados de um bebê, e, por outro lado, a lousa, no senso comum, estava geralmente associada ao ofício de uma professora, como foi expresso em depoimentos ao longo da pesquisa. Nessa perspectiva, ao utilizar a expressão "entre a fralda e a lousa" no título deste trabalho, quisemos intencionalmente evocar essa busca de significados, representações e identificações implicados nesse novo campo do magistério e os muitos sentidos atribuídos aos fazeres de uma professora que atua com bebês, considerando o seu percurso profissional e as transformações ocorridas recentemente na instituição.
Neste estudo as identidades docentes são consideradas como uma das formas identitárias sociais, tidas não como fixas, permanentes ou essenciais, mas como identidades que se formam e se transformam continuamente, até mesmo de maneira contraditória, em interação com diferentes momentos históricos e diversos sistemas de significação social e representação cultural (Hall, 2005). O autor usa a ideia de articulação para caracterizar a identidade como um ponto de encontro entre discursos e práticas que dirigem os sujeitos para assumir determinadas posições sociais e, por outro lado, o processo de construção de subjetividades que produzem os sujeitos. As identidades seriam, portanto, "pontos de apego temporário às posições-de-sujeito que as práticas discursivas constroem para nós. Elas são o resultado de uma bem-sucedida articulação ou 'fixação' do sujeito ao fluxo do discurso" (Hall, 2009b, p. 112).

A questão dasidentidades docentes como uma forma de governo dos professores é abordada por Lawn (2000), que afirma ser esta uma parte importante do discurso oficial. Por meio de projetos educacionais e publicações de várias naturezas, referentes ao âmbito escolar ou de maior amplitude, discursos são veiculados para impor modificações reguladoras às comunidades docentes. Certamente essas propostas não são assimiladas integralmente nas escolas, passando por processos de resistência e reinvenção local, tanto no que se refere às indicações curriculares como aos ideais identitários docentes ou outros aspectos. É importante considerar tais questões reguladoras, mas também é necessário voltar o olhar para aspectos processuais de reconstrução dessas identidades em outros níveis, ao longo da vida pessoal e profissional de docentes e de outros profissionais da educação.

A configuração do campo de pesquisas sobre identidades docentes é relativamente 
recente, a partir do final da década de 1980, com várias conceitualizações para o tema e diversas abordagens metodológicas para seu estudo, conforme a síntese elaborada por Beijaard, Meijer, e Verloop (2004). Marcelo (2009) procura indicar constantes identitárias para a profissão, enquanto Garcia, Hypolito e Vieira (2005) constroem modelos profissionais docentes. Há muita diversidade de pesquisas na área, mas a maioria dos autores que se dedicam a esse estudo concorda que as identidades docentes não são construções fixas e imutáveis, e sim formas reflexivas que indicam várias possibilidades de análise. Dentre tantas possibilidades, pretendemos estabelecer associações entre processos de construções identitárias e diferentes culturas, relações de poder e gênero que permeiam uma instituição de atendimento à infância em um determinado tempo e lugar.

Para entender as origens das unidades infantis que, na atualidade, atendem a crianças pequenas na cidade de São Paulo e o atual formato da profissão que, hoje, se ocupa dessa atividade, fizemos uma breve incursão na história das instituições de educação infantil no Brasil através de estudos realizados por Del Priore (2002), Kishimoto (1988), Kuhlman Jr. (2004), entre outros. Nessa análise observamos a existência de um passado extremamente carregado por desigualdades sociais e distinções de classes, cujos reflexos vivemos até aos dias de hoje. O processo de colonização e o fenômeno da escravidão, que coexistiam ao lado de - e sustentando - uma pequena elite dominante, davam o tom à forma dualista com que também a infância seria tratada: por um lado, havia as crianças escravas, as crianças órfãs, os filhos de camponeses, os filhos de imigrantes, que eram recebidos em rodas dos expostos, asilos, orfanatos, creches filantrópicas e, num passado mais recente, em parques infantis; e, por outro lado, as crianças de classe abastada que eram cuidadas por amas de leite, amas-secas, criadas, etc., e que, quando crescidas, eram encaminhadas para os jardins de infância.

No que se refere às instituições públicas de atendimento à infância, foi se estabelecendo uma divisão entreaquelas decaráter assistencial, em que, de modo geral, as profissionais ou voluntárias cuidavam das crianças pobres, e as de caráter instrucional, em que as professoras educavam as crianças ricas. Essa dicotomia foi delineando a história da educação infantil no Brasil, conforme explicam as autoras:

Dessa forma, pode-se considerar que, na faixa de 0 a 6 anos de idade, consolidaram-se dois tipos de atendimento paralelos: o que se convencionou chamar creche, de cunho mais assistencial e de cuidado, e a pré-escola, ligada ao sistema educacional e refletindo suas prioridades de caráter instrucional. (Campos, Rosemberg, \& Ferreira, 2006, p. 104)

Analisando ainda aspectos da história da educação infantil, verificamos também que os cuidados das crianças pequenas passariam a ser, tanto a nível doméstico quanto institucional, um objeto da ciência médica. Os higienistas, como discutem Gondra (2002) e Viviani (2007), pretendiam contribuir com seus preceitos sobre higiene, saúde e alimentação, etc., desde o século XIX, garantindo o progresso da nação. Por isso, era preciso abandonar as crendices e ensinar as mulheres que não detinham o conhecimento científico a cuidarem de maneira adequada dos bebês, deixando-nos culturalmente mais uma herança: a crença na supremacia do saber científico sobre o saber popular.

Já no início do século passado observamos que a gênese dessa profissão estava também relacionada aos movimentos sociais de resistência, influenciados por ideias 
anarquistas, que reivindicavam melhores condições de vida para operários, crianças e mulheres, e que vieram tomando corpo por meio dos movimentos sociais e populares. Conforme aponta Rosemberg (1984), entre outros fatores, o crescente desenvolvimento urbano e industrial da cidade, bem como a inserção das mulheres no mercado de trabalho e também as conquistas dos movimentos feministas, deflagrariam, após o período da Ditadura Militar, um investimento na implantação de creches públicas na cidade de São Paulo. Do mesmo modo, no período de abertura política no Brasil toda essa dinâmica política e social impulsionaria a criação de um conjunto de leis e normativas voltadas à proteção da infância e à estruturação da educação infantil como etapa da educação básica no país. ${ }^{1}$

Nas últimas três décadas, muitas mudanças ocorreram no contexto das creches em São Paulo, e, consequentemente, em seus quadros de profissionais, o que pode ser observado nas próprias mudanças na denominação da função: pajem nas primeiras unidades na década de 1980; auxiliar de desenvolvimento infantil (ADI) a partir de 1984; professora de desenvolvimento infantil (PDI) em 2003, após o período de transição das creches para a Secretaria Municipal de Educação; até à recente definição de professora de educação infantil (PEI), em 2007. Muitas professoras, que ainda hoje trabalham em CEIs, passaram por todas essas fases e continuaram a exercer as suas funções no trabalho com crianças pequenas, tendo como cenário esse transitar entre diferentes concepções e discursos da instituição.

A proposta da realização da pesquisa e seus objetivos foram apresentados à equipe administrativa e docente do CEI Freireano durante uma reunião pedagógica, momento em que puderam esclarecer todas as suas dúvidas a respeito do processo de entrevistas. Foi solicitada a adesão voluntária ao estudo e sete professoras e um professor aceitaram participar, assinando um termo de consentimento livre e esclarecido, inclusive em relação à gravação das entrevistas, em que era garantida a confidencialidade e o sigilo quanto às suas identidades, através da adoção de nomes fictícios escolhidos pelos próprios sujeitos envolvidos. Foi também solicitada a autorização da Diretoria Regional de Educação a que o CEI estava subordinado para a realização da pesquisa. Dentre os sujeitos que participaram da pesquisa, duas docentes iniciaram as suas atividades na instituição como pajens, três como ADIs, um como PDI e duas como PEI. Dessa forma, o grupo de entrevistados se constituiu de forma heterogênea no que se refere a sexo, idade, diferentes percursos profissionais e escolaridade, entre outros aspectos.

Ao elegermos uma abordagem qualitativa, com apoio em Bogdan e Biklen (1994), tivemos

\footnotetext{
${ }^{1}$ De acordo com Campos et al. (2006), a Constituição Federal promulgada em 1988 no Brasil foi a primeira a fazer referências a direitos específicos das crianças de 0 a 6 anos de idade e a reconhecer como dever do Estado o seu atendimento em creches e préescolas. Mais tarde, em 1990, a criação do Estatuto da Criança e do Adolescente - ECA (Lei n 8.069, de 13 de julho de 1990) veio reafirmar essa concepção da criança como sujeito de direitos, indicando que é dever do Estado assegurar às crianças de 0 a 6 anos o atendimento em creches e pré-escolas. Em consonância com tais concepções sobre a infância, em 1996 foi promulgada a Lei de Diretrizes e Bases da Educação Nacional - LDB (Lei n 9.394, de 20 de dezembro de 1996). A educação nacional passou a organizarse em dois níveis: 1) educação básica, composta pela educação infantil, ensino fundamental e médio, e 2) educação superior. Nessa nova organização, as creches, anteriormente vinculadas a órgãos de assistência social, passaram a ser também consideradas como equipamentos de educação infantil, elevando-se ao patamar de primeira etapa da educação básica.
} 
como intenção utilizar uma metodologia que nos auxiliasse na busca de significados e sentidos que professoras e professores de educação infantil vêm construindo em sua prática no atendimento de bebês no contexto institucional, tendo como ponto de partida as suas próprias vivências e as formas como interpretam as suas experiências profissionais.

A condução do estudo empírico se deu por inspiração no método biográfico, pois este, segundo Moita (2007), permite "compreender, de um modo global e dinâmico, as interacções que foram acontecendo entre as diversas dimensões de uma vida" (p. 116). Não houve, no entanto, a pretensão de abordar todos os aspectos biográficos de cada participante, mas o convite, durante as entrevistas aos sujeitos da pesquisa, a falarem abertamente sobre quatro temas centrais para a condução da pesquisa: suas histórias de vida, sobretudo suas trajetórias profissionais; as representações e expectativas sobre suas identidades profissionais como docentes; as suas opiniões sobre as questões de gênero que permeavam a atividade profissional com bebês; e, por fim, as suas percepções sobre os fazeres e saberes desenvolvidos em berçários.

Nóvoa (2007) ressalta que, na atualidade, a atenção concedida às abordagens biográficas (ou autobiográficas) no campo científico é reflexo de um movimento social mais amplo e de uma mutação cultural, a partir dos quais se faz "reaparecer os sujeitos face às estruturas e aos sistemas, a qualidade face à quantidade, a vivência face ao instituído" (p. 18). Bueno (2002) explica que, nessa viragem, sobretudo nas ciências da educação, a subjetividade passa a se constituir na questão central das novas formulações teóricas e propostas no campo educacional.

Apesar de bem consolidadas no campo das pesquisas educacionais, as abordagens biográficas vêm recebendo algumas críticas, referentes a uma possível inconsistência metodológica, pela presença de fortes referências a aspectos individuais e subjetivos. Em resposta a isso, Ferrarotti (1991) recorre a argumentações que vão de Marx a Sartre, afirmando que toda a práxis humana revela as apropriações que o indivíduo, por meio de suas relações, faz das estruturas sociais. No entanto, como sugerem Bueno (2002) e Ferrarotti (1991), partimos do pressuposto de que a relação entre a história individual e a história social não se dá de forma linear, nem determinista, pois cada indivíduo é um sujeito que se (re)constrói de forma singular.

As entrevistas foram realizadas no decorrer do segundo semestre de 2011 nas dependências do CEI, com exceção do encontro marcado na residência da professora Laura, por ela estar afastada devido a problemas de saúde. A duração das entrevistas foi variável, dependendo da necessidade de expressão manifestada por cada docente. Algumas foram realizadas em dois encontros de cerca de uma hora e meia, outras em apenas um período, em um mesmo dia, sendo todas gravadas e posteriormente transcritas em sua totalidade. Assim, foi possível estabelecer um diálogo aberto com as docentes e o docente sobre as suas experiências pessoais e profissionais a partir de um convite para que falassem, inicialmente, sobre seu histórico pessoal e social. Ao longo da entrevista foram abordados os temas elencados acima, muitas vezes de forma espontânea, pelas professoras e professor, ou então mediante indicação da pesquisadora.

Convém destacar que, como uma das autoras estava inserida no contexto investigado, não apenas como pesquisadora, mas também como diretora de escola, embora atenta ao caráter científico da pesquisa, não se buscou, em nenhum momento, uma pretensa neutralidade. As percepções objetivas e 
subjetivas que surgiam no transitar entre esses dois papéis foram consideradas na elaboração deste estudo.

Por se tratar de uma investigação baseada em aspectos biográficos, procuramos ainda estabelecer um percurso metodológico que, embora buscasse compreender os aspectos objetivos e subjetivos do universo pesquisado, não incorresse em interpretações generalizantes.

\section{SETE PROFESSORAS, UM PROFESSOR, MUITAS HISTÓRIAS: O BERÇÁRIO COMO ESPAÇO FEMININO}

Com base nas narrativas das professoras e do professor que participaram da pesquisa, e sendo esta inspirada na metáfora utilizada por Juliá (2001) para definir a necessidade de se conhecer as culturas escolares a partir do interior da instituição, buscamos abrir a caixa preta do CEI Freireano e verificar: quem eram tais docentes; como foram as suas trajetórias de vida e os seus percursos profissionais; de que modo desenvolviam o seu trabalho com bebês; quais eram as práticas que realizavam nas diferentes fases da instituição; em que conhecimentos apoiavam o seu trabalho; como se estabeleciam as relações entre professoras, bebês, mães, instituição, etc.

Um primeiro aspecto que se destaca na análise de suas histórias de vida é o fato de que todas as docentes e o docente são, de origem, de classes trabalhadoras, como lavradores, operários, domésticas, professores ou outras atividades precárias, como a de "limpar peixes", conforme mencionado por Laura. Apenas uma docente, Monique, se refere à mãe como "microempresária", contudo numa oficina de costura instalada em sua própria casa, e Maria Cecília, em um determinado período de sua vida, trabalhou como autônoma em um bazar de sua propriedade. Todas as entrevistadas e o entrevistado, considerando-se as diferenças sociais e econômicas de cada um/a, vêm de famílias pobres, ou de classe média baixa, algumas buscando melhores condições de vida nos grandes centros urbanos, como Lila e Joyce, e algumas em situações de extrema miséria, como contou Laura:

E nas sextas-feiras ela dava aula de... Como que era o nome?... 'prendas domésticas', a gente tinha porque a maioria das alunas saía e ia trabalhar de empregada doméstica. Então ela dava aula, ela levava na casa dela, ensinava como era lavar o banheiro (porque minha casa tinha privada, não era um banheiro), ensinava como lavar a louça, como limpar um fogão, como limpar o chão... mas ela que fazia, a gente só ficava olhando. $\mathrm{E}$ depois ela fazia pão num forno que ela tinha no quintal e dava café pra gente. Então, pra nós, ir pra escola, naquela época, era uma festa, era uma alegria porque a gente não tinha isso em casa. (Entrevista professora Laura)

Embora a maioria tenha nascido na cidade de São Paulo - com exceção de Laura e Luiza -, suas famílias vêm de diferentes procedências: Bahia, Pernambuco, Paraná, Adamantina, outras cidades do interior de São Paulo, com referências também a imigrantes portugueses, italianos e descendências africanas e indígenas. Todas as docentes e o docente, porém, trazendo as vivências dessas diferentes regiões e culturas, se encontram em diferentes momentos históricos, na capital paulistana, num ambiente urbano, para desenvolver uma atividade profissional com crianças pequenas numa instituição pública.

Partindo de diferentes expectativas e necessidades, todas as docentes e o docente chegaram à profissão tendo como ponto comum o surgimento de uma oportunidade de trabalho em um serviço público em expansão: a rede de creches ou CEIs. De uma maneira geral, todas as professoras, como também o professor Júlio, mostraram em seus relatos que a sua inserção 
na profissão se deu como forma de abraçar uma oportunidade de ingressar na rede municipal de ensino, que oferecia mais vantagens aos seus profissionais no que se refere à estabilidade no emprego, melhores salários, ou ainda o fato de abrir novas possibilidades para suas carreiras.

Nessa primeira análise de seus depoimentos, observamos também que a escolha em trabalhar nos berçários - em vez de em outras turmas de crianças maiores que havia no CEI - nem sempre se dava por uma opção das professoras e professores, mas seguia critérios normativos da instituição, em que profissionais há mais tempo na carreira tinham prioridade frente aos mais novos.

Todavia, perpassando todos os aspectos evidenciados no decorrer da pesquisa, a questão que nos salta aos olhos é como essa profissão foi se constituindo, ao longo dos tempos, como uma atividade feminina. Do grupo de docentes entrevistados, sete são mulheres e apenas um, Júlio, que ingressou mais recentemente na instituição, aparece de maneira singular, representando a tímida presença masculina no cenário do CEI Freireano, onde, dos 54 profissionais que atuavam naquela instituição, apenas dois eram do sexo masculino. Entretanto, através das narrativas das professoras e do professor, e apoiadas em estudos de gênero, observamos que o caráter feminino do trabalho com crianças pequenas não se deve apenas à predominância de mulheres que atuam nessa carreira, mas, principalmente, ao fato de os cuidados dos filhos e da casa serem culturalmente considerados um atributo natural das mulheres, como bem expressa o depoimento da professora Joyce:

Praticamente eu criei meus filhos em CEI. Quando eu entrei na prefeitura eu estava grávida, bem de pouquinho, e meu filho mais velho tinha 1 ano e 8 meses... Foi muito gratificante porque, na época, pra mulher trabalhar era muito difícil.
Quem iria olhar duas crianças pequenas? Se eu fosse pagar, não compensaria o salário. A prefeitura, pra mim, foi uma bênção. Um lugar que você vai, trabalha, cuida de outras crianças e sabe que seus filhos também estão sendo cuidados. (Entrevista professora Joyce)

Com base em proposições de Ariès (2006) e Badinter (1985), encontramos algumas explicações sobre como as mulheres se tornaram responsáveis pela criação dos filhos e como, a partir da Revolução Industrial e do surgimento da família nuclear, esse papel veio a se demarcar na estrutura das sociedades modernas - fato este que também viria a influenciar a carreira do magistério, que se tornou reconhecidamente feminina (Carvalho, 1999; Louro, 2002). A partir de vários relatos, ficou perceptível que, nos cenários da instituição, os cuidados com os bebês tinham como referência papéis sociais masculinos e femininos:

No trabalho, a mulher eu acho que é mais carinhosa, mais amorosa do que o homem, a gente foi criada assim. Homem é mais seco, mais durão. Em casa, eu que lambo [fazendo uma analogia com o comportamento da fêmea que lambe o seu filhote], que faço tudo, e meu marido ali. Tem que ter a parte dura e a parte sensível que afaga, que dá carinho, e aqui na escola também. A mulher já traz consigo, da criação, mais carinho, mais aconchego. Aqui na escola fica complicado a hora de fazer o 'duro'. Geralmente, a gente trabalha em duas. Uma é o lado mais enérgico, eu sou aquela que estraga. (Entrevista professora Joyce)

Essa divisão binária de papéis de gênero evidenciou-se, sobremaneira, nos depoimentos do docente acerca dos seus esforços em encontrar estratégias para tornar-se professor num campo reconhecido como feminino e se manter em seu papel social como homem. Durante a sua 
entrevista, ele relatou um fato curioso que ocorreu na primeira unidade infantil em que trabalhou:

Teve vários fatos engraçados! Eu saía de lá direto para a faculdade, e eu ficava acabado com aquelas crianças! Nas construções antigas de creche tinha um vestiário de funcionários e a diretora me autorizou a tomar banho no final do expediente. Eu trancava a porta e colocava uma plaquinha no banheiro 'Cuidado, o professor Júlio está tomando banho!'. Teve um dia que uma mãe viu e fez um auê dizendo que havia um professor pelado no CEI, e eu não pude mais tomar banho antes de ir para a faculdade. (Entrevista professor Júlio)

Esse fato, considerado engraçado pelo docente, expressa claramente, numa ótica foucaultiana (Foucault, 1988), que as questões de gênero, a sexualidade, o discurso sobre os papéis que cada sujeito deve desempenhar, a natureza das relações nas instituições, bem como a própria organização concreta dos espaços, são imperativos culturais que exercem um poder disciplinar que regula a vida em sociedade e controla os indivíduos e seus corpos. É um exemplo que mostra, de forma contundente, que o CEI, como vimos anteriormente, é um território "do feminino", e que a presença de um professor do sexo masculino representaria, por esse motivo, uma espécie de transgressão. Talvez o que estivesse em jogo ali fosse também o desvelar da existência concreta da corporeidade masculina e feminina e a explicitação da materialidade dos sexos num ambiente em que a professora, culturalmente, era considerada como um ser "assexuado" (Cruz, 2011; Louro, 2003), e o homem, em contrapartida, como portador de uma sexualidade incontrolável (Sayão, 2005). Desse modo, a convivência com o professor Júlio, por ele ser homem, ofereceria riscos às mulheres e às crianças daquele lugar.
Essa presença masculina num ambiente feminino colocava em cheque as relações de poder que permeavam a instituição e provocavam reações de todos os sujeitos envolvidos nessa rede - representantes da instituição, famílias, crianças, colegas de trabalho e o próprio docente -, o que se manifestaria nas situações cotidianas, como vimos no depoimento do professor Júlio sobre o conflito desencadeado por ele pleitear o simples direito de tomar um banho. $\mathrm{O}$ próprio docente a todo o momento se indagava se era legítimo ou não, como homem, ocupar aquele lugar "reservado para mulheres". Por isso, Júlio precisava "pedir licença" para adentrar naquele território, como simbolicamente o fez, colocando um recado na porta do banheiro para evitar constrangimentos das colegas.

Mesmo sem muita habilidade, o professor, observando as profissionais mais experientes, aprendeu a trocar os bebês, assim como demonstrou ter tomado várias outras iniciativas no sentido de encontrar o seu jeito próprio de trabalhar nos berçários. A sua atitude colocava em cheque, na instituição e em seu meio social, o fato de que tais tarefas não eram da natureza da mulher, mas sim culturalmente aprendidas por elas (e também por ele naquela profissão). No cotidiano do CEI Freireano, o professor procurava se dedicar também a outras tarefas reconhecidas como masculinas, como carregar os bebês mais pesados ou colocar limites nas crianças mais velhas. Todavia, ele evitava trocar as fraldas das meninas, o que, moralmente, estaria colocando em risco a segurança das crianças:

Eu troquei ela, embora eu sempre evite trocar as meninas, só quando não é possível. Eu tenho muito receio com os espectadores, porque, por exemplo, se a menina fez cocô, você tem que lavar direitinho a vagina da bebê, ou passar bem o lencinho umedecido, e a pessoa não compreende. Eu mesmo já ouvi uma moça da limpeza falando 
'olha ele cutucando a menina!'. Ainda bem que a outra falou 'não, sua besta, ele é o professor!'. (Entrevista professor Júlio)

A experiência do docente elucidava o rigor com que também as relações profissionais, no âmbito da instituição, se pautavam numa ótica heteronormativa (Butler, 2003). Para Butler (2003), essa ótica binária e essencializante que define os códigos sociais de como um homem e uma mulher devem se comportar atravessa e classifica todas as relações sociais, incidindo até sobre os próprios corpos dos sujeitos, e, nesse caso, também sobre a sua identificação como profissionais.

Ao contrário do professor (homem), ao serem indagadas sobre como haviam aprendido a cuidar de bebês, a grande maioria das docentes (mulheres) mencionou as suas experiências pessoais com os seus próprios filhos e que haviam aprendido tais cuidados com suas mães e, assim, de geração em geração. Havia uma queixa geral de que as questões específicas envolvendo o trabalho desenvolvido com os bebês não eram abordadas nos cursos de magistério ou pedagogia e também não eram priorizadas nos processos de formação continuada promovidos pela Secretaria Municipal de Educação. Ficou notório que, ao ingressar no cargo, e especificamente no trabalho em berçários, ao não propor treinamentos específicos para esse trabalho, a instituição contava com o fato de que as profissionais já possuíssem previamente tais saberes, reafirmando a crença de que o cuidado das crianças era um atributo natural das mulheres, como explicou Maria Cecília:

A gente vai aprendendo como lidar com a criança, como lidar com o bebê. A gente estuda, mas a gente aprende a teoria, agora a prática já tem que ser uma coisa assim... Já teve pessoas que entraram no CEI e aprenderam a trocar a fralda aqui mesmo. Ou então o bebê de quatro meses acabou de comer e a pessoa já foi colocar no berço, e a gente teve que orientar: 'não, não, tem que virar!'. Então, alguém tem que falar, ou então, pra aprender, vai ter que consultar um livro de saúde! Porque no livro de saúde você vai achar, por exemplo, que a criança, após o mamar, tem que arrotar. Porque não vai estar no currículo. Porque isso não vai ser ensinado no magistério ou na pedagogia. (Entrevista professora Maria Cecília)

\section{FAZERES, SABERES E PODERES NAS RELAÇÕES PROFISSIONAIS COM BEBÊS}

Durante as entrevistas, o uso recorrente de expressões como "de geração em geração", "conhecimento visual", "empírico", "experiência de ver muito", entre outras, deu pistas de que um dos aspectos centrais da docência em berçários é a questão da experiência. Bondía (2002) explica que a educação vem sendo pensada a partir de dois pontos de vista: $o$ teórico e o prático ou o científico e o tecnológico. Segundo o autor, as concepções positivistas consideram a educação uma ciência aplicada. Já as abordagens críticas a consideram como uma prática reflexiva. E tanto uma quanto a outra determinam o que pode ser dito ou não nesse campo. A experiência, que não permite universalizações por ser única e singular, é considerada um tipo de conhecimento menor, quando muito um ponto de partida a ser transposto, e, por esse motivo, é rechaçada pela ciência e pela filosofia.

Evidenciou-se, nos relatos das docentes e do docente, que, embora a experiência, como discute Bondía (2002), representasse uma fonte de saberes relevante nos cuidados dos bebês, esses conhecimentos práticos relacionados ao cuidar não eram valorizados em contextos escolares (Carvalho, 1999), onde a ênfase era dada aos aspectos cognitivos, e isso também, de certo modo, regulava os discursos 
das docentes e do docente a respeito de suas próprias práticas:

Os passeios em torno do CEI para observar as coisas, observar os pássaros, as plantinhas, as joaninhas... então era tudo um trabalho assim montado... E a gente punha uns nomes assim chiques: 'vamos trabalhar a expressão corporal', 'vamos trabalhar a observação da natureza', 'vamos trabalhar a rotina diária'. Coisas simples, mas que se dá um nome mais pedagógico. (Entrevista professora Laura)

No que se refere ao planejamento das atividades nos berçários, de um modo geral, as narrativas apontavam para a existência de uma regularidade no planejamento das ações desenvolvidas, embora o caráter da imprevisibilidade fosse frequente, já que, embora tentassem seguir o planejamento, havia um consenso de que era importante respeitar o ritmo e as manifestações das crianças, sobretudo em situações em que, por exemplo, os bebês quisessem dormir em vez de participar de outra atividade prevista para aquele horário.

No nosso dia a dia a gente recebe eles, pergunta como foi a noite deles, e aí a gente vai organizando eles pro café da manhã. Dá o café da manhã, em seguida faz a troca, aí a gente vai pra uma atividade. No momento, a gente vê o que eles querem fazer. Eles sabem o que querem. Não adianta dar a bola se eles não estão interessados. O tempo tá bom, a gente vai dar uma volta, ou vamos pra outra sala fazer uma integração, que também é válido, conhecer outros amigos, outros professores. Aí chega a hora da outra troca; se necessário, o banho. Já chega o almoço e a gente vai fazer a alimentação deles. A gente dá mais uma olhada se está tudo ok de troca e já põe pra descanso, é a hora do soninho. Aí já chega a hora de fazer o nosso relatório do dia, relatar tudo o que aconteceu, a atividade que a gente deu. Eles vão dormir e a gente espera o colega chegar pra sair da sala. Aí é aguardar um novo dia! (Entrevista professora Luiza)

Embora as narrativas mencionassem a diversidade de atividades e linguagens como um ideal a ser atingido no trabalho em berçários, também foi unânime a referência à importância da afetividade como um aspecto central desse trabalho:

Na minha opinião, na escola ideal, você tem que ter primeiro o carinho, o amor por aquilo que você está fazendo, seja uma música, um gesto, uma bronca. Afetividade em primeiro lugar. (Entrevista professora Joyce)

Os bebês, o que eles querem é bastante carinho, bastante afeto. A gente acha que eles não entendem, mas eles entendem muito, viu? Os bebês querem carinho e atenção, eles querem respostas. Se a criança puxa o pelinho e ele voa, ele quer que você esteja lá do lado dele. (Entrevista professor Júlio)

Alguns depoimentos, porém, mencionaram também a dificuldade enfrentada em garantir um atendimento das necessidades afetivas de cada criança devido ao número de crianças pelas quais são responsáveis nos berçários, como concluiu o professor Júlio: "O difícil é estar ao lado de cada um e de todos com qualidade".

\section{DOCÊNCIA EM BERÇÁRIOS: TRANSITANDO PELAS FRONTEIRAS DAS IDENTIDADES PROFISSIONAIS}

Hall (2005, 2009a), em suas proposições sobre cultura e identidade, analisa a diáspora, ou o mito diaspórico, como um processo social em que, ao mesmo tempo em que o 
sujeito mantém laços com a terra de origem que abandonou, ele também passa a ter como referência identitária aspectos da nova cultura do outro lugar que passou a habitar.

Nesse sentido, se, metaforicamente, considerarmos a passagem das creches de uma Secretaria de Assistência Social para uma Secretaria de Educação - conforme ocorreu na cidade de São Paulo - como uma espécie de diáspora institucional, que representações emergiriam a partir do encontro dessas diferentes culturas no âmbito da instituição, que teve, inclusive, entre outras mudanças estruturais, sua denominação alterada para centro de educação infantil? Essa foi a indagação que se evidenciou a partir e no decorrer da análise dos depoimentos das docentes e do docente que participaram da pesquisa, que, de maneira direta ou indireta, manifestaram suas impressões sobre esse embate de culturas assistenciais e educacionais a partir do qual se desenvolvia a sua experiência profissional em berçários, naquele momento da instituição.

Em seus relatos a respeito do passado das creches, as memórias evocadas expressavam uma imagem sombria em que bebês ficavam "presos em quadrados", em que as relações de poder eram extremamente verticalizadas e as pajens ou ADIs, além de suas tarefas com as crianças, realizavam todo o tipo de trabalho, como limpar as salas ou preparar as refeições. Os discursos criavam uma imagem nebulosa, embora uma ou outra docente esboçasse certo saudosismo ao referir-se às amizades ou atividades prazerosas que havia realizado naquela época. Evidenciava-se um julgamento negativo acerca do passado das creches como um discurso predominante na instituição e o momento de inserção dos CEIs na rede de ensino representaria uma espécie de "transformação" ou "redenção" dessa realidade:
De um tempo passado que ouvi falar, acho que houve avanços na instituição, saiu dessa visão realmente assistencialista, depósito de criança, pra uma evolução da concepção do que é essa criança que a gente atende, não um amontoado. (Entrevista professora Monique)

Com relação aos bebês, mudou muito. Antigamente, os bebês eram vistos... põe lá, dá comida, dá mamadeira, dá banho, troca fralda e dorme. O bebê hoje ele pula, o bebê hoje ele canta, o bebê hoje ele corre, ouve histórias. (Entrevista professora Isabel)

Em suas narrativas, as docentes, cada qual a seu modo, demonstraram estar ajustando esses dados da realidade de sua prática profissional aos discursos atuais da instituição com relação à necessidade de integração entre o cuidar e o educar. Entretanto, em sua prática cotidiana nos berçários, muitas tarefas relacionadas ao cuidado da criança ainda eram as mesmas do passado, colocando em jogo o seu novo papel como docentes. A análise negativa do passado da instituição parecia servir também como uma forma de valorizar a sua condição presente como docentes, ainda que tivessem tarefas diferenciadas das demais colegas da rede de ensino, em relação aos cuidados da criança.

Em meio às muitas falas referentes às tais práticas de cuidados no decorrer de todo o processo de entrevistas, a referência às tarefas relacionadas aos excrementos dos bebês, ou ao xixi e ao cocô, emergiu em seus discursos como um emblema que demarcava a dicotomia entre trabalho intelectual e trabalho manual, e que diferenciava docentes que atuavam com bebês daqueles que atuavam com crianças maiores no próprio âmbito do CEI, ou entre outras unidades de educação infantil, ou ainda em comparação com outros níveis de ensino, 
como expressa o depoimento da professora Lila:

Estou procurando ver com outros olhos. Eu não posso ser hipócrita e falar pra você que foi tudo bonitinho. Foi conflituoso, frustrante.

A Lila sempre foi professora, mas agora ela está colocando a mão na merda. Mas agora esses preconceitos estão mudando. (Entrevista professora Lila)

O discurso em torno da indissociabilidade entre o educar e o cuidar, por mais que atrelasse o cuidado às práticas docentes, o colocava, ainda que implicitamente, numa situação de tarefa menos nobre. Desse modo, o julgamento depreciativo que se fazia do passado da instituição criava uma situação contraditória, pois, se tudo aquilo que se fazia antigamente era considerado negativo, como fazer parte desse modelo atual focado no educar e ainda continuar lidando com o xixi e o cocô?

Numa abordagem sociológica, para discutir o processo de construção identitária, Dubar (2005) se utiliza dos conceitos de atos de atribuição, para explicar as definições sociais a respeito daquilo que o sujeito é (identidade para o outro), e de atos de pertencimento, que estão relacionados com aquilo que a pessoa quer ser (identidade para si). Diante da proposta de expressar a imagem de um docente "ideal", com base no pensamento do autor, pudemos observar que havia uma identidade atribuída à sua atuação com bebês e outra que as professoras e o professor de fato queriam ser. Nesse processo, evidenciaramse as diferentes estratégias identitárias às quais tais sujeitos recorriam para se sentirem próximos às suas representações em torno da carreira do magistério e também como meio de valorizar a sua profissão.

Do que pudemos depreender da análise de suas narrativas, as docentes e o docente justificavam sua permanência no cargo e o valor da sua profissão devido à paixão pelo trabalho com bebês ou ainda pela retribuição afetiva que as crianças pequenas manifestavam, dando sentido aos seus esforços, que nem sempre eram socialmente reconhecidos. As professoras que estavam há mais tempo no trabalho em berçários manifestaram a sua satisfação em ajudar as mais novas com a experiência que possuíam sobre os cuidados das crianças. Outras afirmaram sentirem-se motivadas pela importância social de seu trabalho, referindose ao papel da professora diante de situações de pobreza e de carência dos bebês e de suas famílias, ou se identificavam com práticas inovadoras no próprio campo da educação infantil. Outras ainda assumiam a proximidade de suas funções relacionadas ao cuidado às de um profissional da saúde, especialmente as das enfermeiras. Porém, um fator mencionado unanimemente, por diversas vezes, diz respeito ao prazer de acompanhar a evolução do bebê, cuja rapidez do desenvolvimento é algo visível nessa idade:

O que me satisfaz no meu trabalho é a alegria de ver a criança começar a engatinhar, andar, o progresso. Às vezes a gente encontra na rua, adulto já... Então a gente vê: a criança ela entra, ela tá no bercinho, não levanta. Aí você acompanha o progresso da criança: a criança começa a sentar, começa a engatinhar, começa a segurar nas coisas pra andar. E isso é muito gratificante. E o trabalho que eu gosto de fazer é esse. (Entrevista professora Maria Cecília)

$\mathrm{O}$ fato de pertencerem ao serviço público municipal, mencionado direta ou indiretamente, também justificava a permanência no cargo, por aspectos relacionados à segurança, ao status e às melhorias salariais que ocorreram após sua passagem para a carreira do magistério no 
âmbito da Secretaria Municipal de Educação, como sugerem os seguintes excertos:

Quando eu comecei a trabalhar no CEI o que eu esperava era que em cinco anos eu já fosse diretor! Ser professor era um rito de passagem. São cinco anos de pré-requisito. (Entrevista professor Júlio)

Hoje, eu acho que tudo o que eu faço eu ganho muito bem pra fazer. Eu tenho que fazer muito bem feito. (Entrevista professora Joyce)

Uma grande conquista é que hoje pertencemos à secretaria da educação. Antes não sabíamos nem ao que pertencíamos. (Entrevista professora Lila)

Analisando, ainda, os diferentes nomes atribuídos ao trabalho com bebês no âmbito da Prefeitura do Município de São Paulo, conforme mencionamos anteriormente, pudemos identificar na legislação, ao longo das últimas décadas, uma espécie de gradação na definição dos perfis profissionais associados à instituição. Inicialmente a denominação pajem identificava-se com o trabalho manual ou com outras profissões socialmente desvalorizadas, como babás ou empregadas domésticas. Após várias modificações, a denominação atual de professora de educação infantil, pertencente à carreira do magistério, foi associada ao trabalho intelectual. Dessa maneira, a instituição foi criando novos sentidos para essa atividade e fabricando novas identidades profissionais docentes.

Por meio dos relatos aqui considerados, foi possível perceber que tais docentes, em seu cotidiano, recorriam a diferentes saberes, crenças, procedimentos, costumes, conhecimentos, ou culturas, para dar conta de seu trabalho com os bebês. Nesse empreendimento, eram evocados: suas memórias da infância; suas experiências com os próprios filhos; as expectativas de todos os sujeitos envolvidos nessa trama; os conhecimentos científicos que traziam de suas formações na área pedagógica ou que adquiriam informalmente na "consulta ao pediatra", ou em "guias para mães"; seus anseios como profissionais da carreira do magistério; entre outros aspectos.

Verificamos que, ali, as suas identidades docentes se constituíam em meio a um processo de hibridação de culturas (Canclini, 2008). Partindo de uma análise do processo de modernização dos países na América Latina, Canclini (2008) nos conduz a uma percepção de que um traço característico da modernidade é justamente a pluralidade. Os cruzamentos socioculturais, por exemplo, entre a cidade e o campo, o que é culto ou popular, o que é tradicional ou moderno, etc., dão origem ao processo de hibridização das culturas. Nessa perspectiva, o autor explica que a própria expansão cultural é uma das causas que intensificam a hibridação cultural, já que diferentes costumes e hábitos se encontram por meio das mídias eletrônicas. Canclini (2008) define ainda que no processo de hibridação das culturas há uma espécie de reorganização cultural do poder, em que, "obliquamente", tais poderes se atravessam ou se revezam - e dão origem a novos arranjos heterogêneos. Entre outras interpretações que foram feitas ao longo da investigação, a partir desse enfoque dos poderes oblíquos, foi possível destacar os poderes exercidos pelas professoras mais antigas na profissão docente em berçários, naquele contexto. Em paralelo às orientações curriculares que referendavam as atividades pedagógicas na instituição, ficou perceptível que, em determinadas situações, os saberes daquelas professoras advindos de suas experiências como mulheres e de seu conhecimento prático revestiam-se de poderes 
diante dos desafios cotidianos no que se referia aos cuidados dos bebês.

Apesar desse caráter plural das culturas que habitavam o CEI Freireano, ou dessas culturas "mestiças", como as denominou Vidal (2009), que revestiam a prática das docentes nas atividades com os bebês, nos discursos dos sujeitos e da própria instituição, suas ações pareciam sempre convergir para o enunciado da indissociabilidade entre o cuidar e o educar, que, embora anunciasse um esforço de integração dessas duas dimensões no atendimento dos bebês, assumia também um caráter binário, ao associar o cuidar às tarefas exercidas no "passado sombrio" das creches e o educar ao "novo patamar" de suas carreiras como docentes. Desse modo, ao identificar o sentido de sua ação como docentes em situações cotidianas, como auxiliar um bebê a deixar as fraldas ou a se alimentar, para reafirmarem o valor de sua profissão como professoras e professor, em seus discursos, destacavam também outras ações didáticas que realizavam, como, por exemplo, "contar histórias" para os bebês.

Essa trama binária que se evidenciava nos discursos dos sujeitos e nos próprios documentos oficiais da instituição deu indícios de que as relações de poder naquele contexto também se estabeleciam por meio da predominância de uma cultura em detrimento da outra: atividades pedagógicas se sobrepunham às atividades de cuidados; atividades relacionadas aos cuidados se distanciavam do conhecimento pedagógico; professoras que atuavam em outros níveis de ensino eram mais valorizadas do que aquelas que trabalhavam com crianças pequenas; professoras que atuavam com bebês questionavam o compromisso das que atuavam em outros níveis de ensino; conhecimentos científicos sobre o desenvolvimento infantil desprezavam os saberes adquiridos na experiência; os costumes tradicionais referentes aos cuidados dos bebês negavam as descobertas científicas; professoras novas julgavam as práticas antigas como ultrapassadas; professoras antigas desconsideravam as contribuições das novas; as condutas do único professor do sexo masculino eram colocadas em cheque pela maioria feminina; a força masculina se destacava sobre a suposta fragilidade feminina em situações cotidianas; entre outras alternâncias de poder e sujeição.

Seja nas narrativas das docentes e do docente ou no discurso da legislação e de documentos normativos, a contínua repetição do discurso que associa o cuidado e o ensino parecia atuar como uma tentativa de autoconvencimento acerca da necessidade de unificação da cisão entre aqueles que trabalham com o corpo e aqueles que trabalham com a mente, o que desde a época colonial demarcava a nossa sociedade, como alertara Kramer (2005). E, nesse processo, tais práticas discursivas incidiam diretamente na própria constituição das identidades dos sujeitos e nas relações de poder que se estabeleciam no interior daquela instituição.

Com base nesse enfoque do hibridismo, que, segundo Hall (2005), é uma das características centrais das identidades que se produzem na atualidade, para além da lente binária que categoriza de forma dicotômica os fazeres de uma professora ou de um professor de educação infantil, foi possível perceber as diferentes docências que se produziam ali naquele contexto específico, tomando forma nas fronteiras das culturas que coexistiam nos berçários do CEI Freireano, como podemos observar nas reflexões do professor Júlio acerca do seu papel profissional diante da sua prática com os bebês:

Eu, diante do meu trabalho, é uma coisa muito 
de lua, como em toda a profissão. Tem dia que eu venho por inércia. Penso: meu Deus, o que eu estou fazendo lá com aqueles bebês? Sempre fui o melhor da turma, sempre me esforcei, me considero bem inteligente, e agora, com esse bando de nenenzinhos que não sabem nem falar o meu nome, o que eu vou ensinar pra eles? Depois eu me empolgo novamente, eu tô ensinando, tô ensinando. Eu demorei pra assumir, vou ser sincero, mas eu gosto de ser professor... Eu gosto de sentir que estou fazendo a diferença, e com eles você faz. (Entrevista professor Júlio)

\section{CONSIDERAÇÕES FINAIS}

Todos os saberes, qualidades, competências e talentos evocados por Joyce, Júlio, Luiza, Monique, Isabel, Maria Cecília, Laura e Lila em sua atuação com bebês não nos remeteram a um único perfil profissional. Ao contrário, através da pesquisa foi possível reconhecer os diferentes arranjos identitários que puderam emergir naquele contexto específico da educação infantil, considerando as distintas culturas que se encontravam, se chocavam, se integravam e se hibridizavam no interior dos berçários do CEI Freireano.

As memórias das mães das docentes e do docente, que, unanimemente, foram mencionadas em suas narrativas, ao se referirem às suas experiências da infância e aos saberes por elas acumulados sobre os cuidados dos filhos, serviam como fonte de inspiração para a prática docente em berçários. Do mesmo modo, informações obtidas de pediatras, de guias para mães, literaturas da área e orientações curriculares da instituição também foram mencionadas pelas professoras e pelo professor. Canclini (2008) afirma que uma pessoa que vai ao médico e ao curandeiro pode se beneficiar tanto dos saberes científicos quanto dos populares, e, em diferentes circunstâncias, uns ou outros, ou ambos, exercerão o poder sobre a saúde do indivíduo. Nessa perspectiva, podemos afirmar que tanto os saberes transmitidos pelas mães através das gerações, quanto as fontes científicas sobre o desenvolvimento infantil, se alternavam em termos de eficiência no trato cotidiano dos bebês e nas relações de poder que se estabeleciam naquele contexto.

Como apontou Hall (2005, 2009b), o sujeito está em constante deslocamento e aquilo que ele é ou com o que se identifica é algo que muda em diferentes posições, tempos, histórias ou culturas que ele habita, como fica evidenciado na fala do professor Júlio, citada acima, sobre as modificações em sua prática e em sua postura diante daquilo que considerava desafios cotidianos da profissão.

Ao conduzir esta investigação através da abordagem dos estudos culturais, pudemos ter a percepção desses entre-lugares em que está se constituindo essa nova prática docente, $o$ que talvez seja um passo decisivo para uma melhor compreensão das suas especificidades, da sua singularidade e do seu valor social, impulsionando-nos também para novas pesquisas e novos olhares para esse campo de atuação profissional.

\section{REFERÊNCIAS}

Ariès, P. (2006). História social da criança e da família (2a ed.). Rio de Janeiro, Brasil: LTC. Badinter, E. (1985). Um amor conquistado: $O$ mito do amor materno. Rio de Janeiro: Nova Fronteira.

Beijaard, D., Meijer, P., \& Verloop, N. (2004). Reconsidering research on teachers' professional identity. Teaching and Teacher Education, 20, 107-128. http://dx.doi. org/10.1016/j.tate.2003.07.001

Bondía, J. L. (2002). Notas sobre a experiência e o saber de experiência. Revista Brasileira de Educação, 19, 20-28. https://dx.doi. 
org/10.1590/S1413-24782002000100003

Bogdan, R., \& Biklen, S. (1994). Investigação qualitativa em educação: Uma introdução à teoria e aos métodos. Porto: Porto Editora.

Bueno, B. O. (2002). O método autobiográfico e os estudos com histórias de vida de professores: A questão da subjetividade. Educação e Pesquisa, 28(1), 11-30. http://dx.doi.org/10.1590/S151797022002000100002

Butler, J. (2003). Corpos que pesam: Sobre os limites discursivos do "sexo". In G. Louro (Org.), O corpo educado: Pedagogias da sexualidade (2a ed., pp. 151-172). Belo Horizonte: Autêntica.

Campos, M. M., Rosemberg, F., \& Ferreira, I. M. (2006). Creches e pré-escolas no Brasil. São Paulo: Cortez/FCC.

Canclini, N. G. (2008). Culturas híbridas: Estratégias para entrar e sair da modernidade (4 ed.). São Paulo: Edusp.

Carvalho, M. P. (1999). No coração da sala de aula: Gênero e trabalho docente nas séries iniciais. São Paulo: Xamã.

Cruz, E. F. (2011). Banheiros, travestis, relações de gênero e diferenças no cotidiano da escola. Psicologia Política, 11(21), 73-90.

Del Priore, M. (Org.). (2002). História das crianças no Brasil. São Paulo: Contexto.

Dubar, C. (2005). A socialização: Construção das identidades sociais e profissionais. São Paulo: Martins Fontes.

Ferrarotti, F. (1991). Sobre a autonomia do método biográfico. Sociologia, Problemas e Práticas, 9, 171-177.

Foucault, M. (1988). História da sexualidade I: $A$ vontade de saber. Rio de Janeiro: Graal.

Garcia, M. M. A., Hypolito, A. M., \& Vieira, J. S. (2005). As identidades docentes como fabricação da docência. Educação e Pesquisa, 31(1), 45-56. http://dx.doi.org/10.1590/ $\underline{\text { S1517-97022005000100004 }}$

Gondra, J. G. (2002). Modificar com brandura e prevenir com cautela. Racionalidade médica e higienização da infância. In M. C. Freitas \& M. Kuhlmann Jr. (Orgs.), Os intelectuais na história da infância (pp. 289-318). São Paulo, Brasil: Cortez.

Hall, S. (2005). A identidade cultural na pósmodernidade $\left(10^{\mathrm{a}}\right.$ ed.). Rio de Janeiro: DP\&A.

Hall, S. (2009a). Da diáspora: Identidades e mediações culturais. Belo Horizonte: UFMG.

Hall, S. (2009b). Quem precisa de identidade? In T. T. Silva (Org.), Identidade e diferença: A perspectiva dos estudos culturais (pp. 103133). Rio de Janeiro: Vozes.

Juliá, D. (2001). A cultura escolar como objeto histórico. Revista Brasileira de História da Educação, 1(1), 9-44.

Kishimoto, T. M. (1988). A pré-escola em São Paulo (1877 a 1940). São Paulo: Loyola.

Kramer, S. (Org.). (2005). Profissionais de educação infantil: Gestão e formação. São Paulo: Ática.

Kuhlmann Jr., M. (2004). Infância e educação infantil: Uma abordagem histórica ( $3^{\mathrm{a}}$ ed.). Porto Alegre: Mediação.

Lawn, M. (2000). Os professores e a fabricação de identidades. In A. Nóvoa \& J. Schriewer (Eds.), A difusão mundial da escola (pp. 6984). Lisboa: Educa.

Louro, G. (2002). Mulheres na sala de aula. In M. Del Priore (Org.), História das mulheres no Brasil (pp. 443-481). São Paulo: Contexto.

Louro, G. (2003). Pedagogias da sexualidade. In G. Louro (Org.), O corpo educado: Pedagogias da sexualidade (2a ed., pp. 7-34). Belo Horizonte: Autêntica.

Marcelo, C. (2009). A identidade docente: Constantes e desafios. Formação Docente, 1(1), 109-131.

Moita, M. C. (2007). Percursos de formação e de transformação. In A. Nóvoa (Org.), Vidas de professores (2a ed., pp. 111-140). Porto: Porto Editora. 
Nóvoa, A. (Org.). (2007). Vidas de professores ( $2^{\text {a }}$ ed.). Porto: Porto Editora.

Rosemberg, F. (1984). O movimento de mulheres e a abertura política no Brasil: $\mathrm{O}$ caso da creche. Cadernos de Pesquisa, 51(1), 73-79.

Sayão, D. T. (2005). Relações de gênero e trabalho docente na educação infantil: Um estudo de professores em creche (Tese de doutorado). Universidade Federal de Santa Catarina, Florianópolis, Brasil.

Vidal, D. (2009). No interior da sala de aula: Ensaio sobre cultura e prática escolares. Currículo sem Fronteiras, 9(1), 25-41.

Viviani, L. M. (2007). A biologia necessária: Formação de professoras e escola normal. Belo Horizonte: Argvmentvm.

\section{LEGISLAÇ Ã O CONSULTA DA}

Lei $\mathrm{n}^{\circ} 8.069$, de 13 de julho de 1990. Dispõe sobre o Estatuto da Criança e do Adolescente. Diário Oficial da União, Brasília, DF, Brasil. Lei $\mathrm{n}^{\circ}$ 9.394, de 20 de dezembro de 1996. Estabelece as Diretrizes e Bases da Educação Nacional. Diário Oficial da União, Brasília, DF, Brasil.
CAUGHT BETWEEN DIAPERS AND THE BLACKBOARD: TEACHER IDENTITIES IN NURSERIES

\section{Abstract}

In this article we present a research on teaching identities in nurseries that was developed at an Early Childhood Education Center in São Paulo (Brazil). Using a qualitative and multidisciplinary approach, the study sought to establish relationships between identity, culture, gender and power, bringing the cultural studies area closer to the field of early childhood education. Inspired by biographical approaches, the empirical study was undertaken through interviews with seven female and one male kindergarten teachers who worked with children aged 0 to 2 years. The analyses indicated that, although the nursery practice involved multiple knowledges and cultures, a binarism regarding the need for caring and educating was produced in the teachers' discourses. Caring was associated with practices of the past, and educating was something closer to their new professional role, representing identity strategies for valuing teaching babies.

Keywords: Teaching identities; Early childhood education; Institutional cultures 
ENTRE EL PAÑAL Y EL PIZARRÓN: LA CUESTIÓN DE LAS IDENTIDADES DOCENTES EN LA EDUCACIÓN INFANTIL

\section{RESUMEN}

En este artículo presentamos una investigación sobre identidades docentes en un Centro de Educación Infantil en la ciudad de São Paulo (Brasil). Mediante enfoque cualitativo y multidisciplinar, el estudio buscó establecer relaciones entre identidad, cultura, género y poder, aproximando el área de los estudios culturales al campo de la educación infantil. Inspirado en abordajes biográficas, la investigación empírica fue realizada por medio de entrevistas a siete profesoras y un profesor de educación infantil, que trabajaban con niños de 0 a 2 años de edad. Los análisis muestran que, a pesar de que la práctica en las escuelas de educación infantil apela a múltiples saberes y culturas, en los discursos de los profesores aparecía una dicotomía entre la necesidad de cuidar y de educar en que cuidar se asociaba a las prácticas del pasado y educar se aproximaba a su nuevo papel profesional, representando estrategias identitarias para valorizar la docencia con bebés.

Palabras Clave: Identidades docentes; Educación infantil; Culturas institucionales

\footnotetext{
I Programa de Pós-Graduação em Estudos Culturais, Escola de Artes, Ciências e Humanidades, Universidade de São Paulo, Brasil. ORCID: 0000-0001-9781-0947

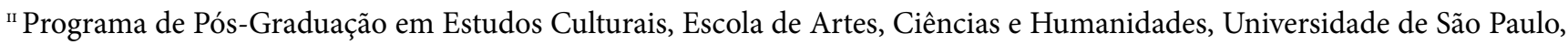
Brasil. Orcid: 0000-0001-7185-9769
} 